\title{
Incidence and Risk Factors of Nosocomial Infections in Neonatal Unit Sanglah General Hospital, Denpasar
}

\author{
Suartawan, Hamid HA \\ Department of Child Health, Medical School, Udayana University, \\ Central Hospital of Denpasar
}

\begin{abstract}
The rate of morbidity due to infection including nosocomial infection during neonatal period is higher than that due to other causes. The purpose of this study was to know the incidence and risk factors of nosocomial infection. This study was conducted on all babies treated at the neonatal unit, Sanglah General Hospital, Denpasar during the period of April-June 1995. Chi square test was used to compare nosocomial infection between birth weight groups and mode of deliveries. The incidence of nosocomial infections in this study was $6 \%$, with male to female ratio of 1.6:1. Skin infections were found most frequently. This occurrence of nosocomial infection was significantly related to the birth weight and mode of delivery, in which the risk of nosocomial infection was greater in babies with low birth weight and delivered by cesarean section or other obstetric procedures. Paediatr Indones $1998 ; 38$; 68-74]
\end{abstract}

\section{Introduction}

Nosocomial infection is localized or systemic infection that occurs after admission to hospital, as an adverse reaction to the presence of an infectious agent or its toxin. The rate of morbidity due to infection, including nosocomial infection during neonatal period, especially during the first few weeks after delivery, is higher than that due to other causes. ${ }^{2}$ Boejang in her study conducted in the neonatal unit of Cipto Mangunkusumo Hospital in Jakarta found that during the year 1982 the number of nosocomial infections in this unit occurs in $540(12.6 \%)$ out of the 4359 babies delivered. ${ }^{3}$ Rain et al found during January-November 1983 in the neonatal unit of Pirngadi

Author's address: Suartawan, MD, Department of Child Health. Medical School, Udayana Univerisity, Denpasar, Bali, Indonesia. Tel. 62-361-27911, Fax. 224206 
General Hospital, Medan, the incidence of nosocomial infection was as many as 499 $(15.74 \%$ ) out of the 3448 babies, of which $83 \%$ were with the birth weight of 2.500 grams or more, and $17 \%$ with birth weight of less than 2500 grams. ${ }^{4}$ Asnil et al found during the year of 1982 in the neonatal unit of Dr. M Jamil Hospital in Padang, the incidence of nosocomial infection of $6.56 \%$, in which enteritis represents the most $(72 \%)$, and of this $63 \%$ occurred in low birth weight infants. ${ }^{5}$

Nosocomial infection in newborn can originate from the mother or from the environment. The causes can be virus, bacteria, fungus, etc, and can affect almost all organs, especially skin, mucosa, lungs, and intestine. The factors contribute to this infection can be grouped into external factor and that from the baby itself. Among the external factors are the mother's hygienic condition, the mother's sickness, babies on formula only, the unclean baby caring equipment, unclean site of baby caring, and cross infection from the medical personnel or even from caring equipment and treatment. While factors from the baby include age, sex, birth weight, and mode of delivery. ${ }^{6,7}$ The purpose of this study was to determine the incidence and risk factors of nosocomial infection in neonatal unit, Sanglah General Hospital, Denpasar.

\section{Methods}

This study was conducted on all babies treated at the neonatal unit, Sanglah General Hospital, Denpasar, during the period of April-June 1995. Excluded from this study were infants whose mothers experienced premature rupture of the membrane, fever before or during delivery, infants with severe asphyxia, infants with central venous line, infants on ventilator, babies on formula only, babies with severe congenital abnormality, and babies born outside Sanglah General Hospital of Denpasar.

The diagnosis of nosocomial infection was established under such criteria as the occurrence of clinical infection symptom which occurs at least after $3 \times 24$ hours treatment which can be in the forms of: ${ }^{7-10}$

- Sepsis, which was diagnosed when at least there was a positive blood culture or the presence of at least 3 out of 6 of the following criteria:

1. General: not doing well, lazy to drink, hypo or hypertonic, sclerema

2. Cardiovascular: tachycardia ( $>160 \mathrm{x} / \mathrm{min}$ ), shock, or poor peripheral circulation

3. Digestive tract: hepatomegaly, vomiting and/or diarrhea

4. Respiratory tract: dyspnea, apnea, cyanosis, tachypnea ( $>60 \mathrm{x} / \mathrm{min}$ )

5. Central nervous system: muscular hypotonia, seizure, lethargy

6. Hematology: pale, jaundice, splenomegaly, bleeding

- Meningitis was diagnosed when there were features of sepsis and PMN $>10 / \mu \mathrm{l}$ in the cerebrospinal fluid.

a Gastroenteritis: frequency of bowel movement was $>4$ times daily with watery stool. 
- Infection of the ear, nose and throat

- Infection of the urinary tract: indicated by laziness, no increase in the body weight, pyuria (leukocyte $>10 /$ high power field), and in the testing of the urine culture are found one of the following results: (1) catheterized urine: $>10,000$ colonies count/ $\mathrm{ml}$; (2) middle portion urine: $>100,000$ colonies count/ml; (3) direct aspiration of the bladder: with the presence of bacteria.

- Lower respiratory tract infection was indicated by fever $\left(>38^{\circ} \mathrm{C}\right)$, cough, dyspnea or rales and confirmed on chest $x$-ray.

- Skin infection: every purulent material on the skin/subcutaneous tissue

Factors considered to have influence on nosocomial infection were sex, birth weight ( $\geq 2500$ grams or $<2500$ grams), mode of delivery (obstetrical procedures, spontaneous, cesarean section).

Blood culture and cerebrospinal fluid examination were done if the patient showed features of sepsis. Urinalysis and urine culture and ENT consultation were done as indicated. The chest $\mathrm{x}$-ray examination was done based on the indication and interpretation done by the radiologist.

Chi square test was used to compare nominal data. The level of statistical significance was $\mathrm{p}<0.05$.

\section{Results}

During the period of AprilJune 1995, 950 babies were recorded to have been treated in the neonatal unit of Sanglah General Hospital, Denpasar; 402 were male and 448 female. Of the 950 babies $180(19 \%)$ had the birth weight of <2500 gram, and 770 babies were with birth weight of $>2500(81 \%)$.

Fifty-eight $(6 \%)$ of the 950 babies was considered to have nosocomial infections; of those, $36(62 \%)$ were male and $22(38 \%)$ were female. Skin infections most frequently found infection; i.e., 34 (59\%) of all infected babies, followed by gastroenteritis ( 8 babies or $14 \%$ ). All types of nosocomial infections can be seen in Table 1 .

Blood culture test was done in 7 babies with sepsis and meningitis. Enterobacteria was found in 4 babies ( 3 sepsis and 1 meningitis). Other microorganisms found in three babies with sepsis 1 was pseudomonas, 1 with bacillus sp, and 1 with staphylococcus.

Table 2 depicts the distribution of nosocomial infection based on birth weight . Table 2 shows, the percentage of nosocomial infection in $<2500$ gram body weight group greater than $>2500$ gram group. This difference of the incidence of nosocomial between the two groups was statistically significant $(p<0.005)$. 
Table 1.Types of nosocomial infection in babies treated during April-June 1995 period

\begin{tabular}{lcc}
\hline Type of Infection & Total & $\%$ \\
\hline Skin infection & 34 & 59 \\
Gastroenteritis & 8 & 14 \\
Acutely otitis media & 6 & 10 \\
Neonatal sepsis & 6 & 10 \\
Rhinopharyngitis & 3 & 5 \\
Meningitis & 1 & 2 \\
\hline \multicolumn{1}{c}{ Total } & 58 & $100 \%$ \\
\hline
\end{tabular}

Table 2. Distribution of the occurrence of nosocomial infection based on birth weight

\begin{tabular}{cccc}
\hline Birth Weight & Infected & Non Infected & Total \\
\hline$<2500$ gram & $21(12 \%)$ & $159(88 \%)$ & $180(1.00 \%)$ \\
$>2500$ gram & $37(5 \%)$ & $733(95 \%)$ & $770(100 \%)$ \\
\hline Total & $58(6 \%)$ & $892(94 \%)$ & $950(100 \%)$ \\
\hline & $X^{2}=12 ; \mathrm{df}=1 ; \mathrm{p}<0.005$ &
\end{tabular}

The risk of occurring nosocomial infection was greater significantly in measured delivery than spontaneous or sc $(\mathrm{p}<0.005)$. The distribution of the occurrence of nosocomial infection based on type of delivery can be seen in Table 3.

Table 3. Distribution of nosocomial infection based on type of delivery

\begin{tabular}{lccc}
\hline \multicolumn{1}{c}{ Delivery mode } & Infected & Non Infected & Total \\
\hline $\begin{array}{l}\text { Obstetric } \\
\text { procedures }\end{array}$ & $20(24 \%)$ & $62(75 \%)$ & $82(100 \%)$ \\
$\begin{array}{l}\text { Spontaneous or } \\
\text { cesarean section }\end{array}$ & $38(4 \%)$ & $830(96 \%)$ & $868(100 \%)$ \\
\hline \multicolumn{1}{c}{ Total } & $58(6 \%)$ & $892(94 \%)$ & $950(100 \%)$ \\
\hline \multicolumn{4}{c}{$\mathrm{X}^{2}=52 ; \mathrm{df}=1 ; \mathrm{p}<0.005$} \\
\end{tabular}




\section{Discussion}

During the period April-June 1995, the incidence of nosocomial infection in neonatal unit, Sanglah General Hospital, Denpasar as many as $58(6 \%)$. This number was smaller than that found in the study conducted by Boedjang in $1982(12.6 \%){ }^{3}$ and Raid in Medan in $1983(15.74 \%) .{ }^{4}$ The differences in the results of those studies might be explained by differences in local condition, year of the study, sampling technique, and definitions of nosocomial infection. It is notoriously known that nosocomial infection may differs with different investigators.

Our seires indicated that in the development of nosocomial infection, male babies outnumbered female babies, i.e. $36(62 \%)$ vs 22 babies $(38 \%)$, giving the male to remale ratio of 1.6:1. Generally male babies are more easily infected than fernale. It is postulated that one X chromosome in male which is involved in the immunoglobulin synthesis, while in the female there are two genes, which make them resistant to infection. "1

Nosocomial infection can occur in almost all organs. ${ }^{7}$ We found skin infection as the most frequently found nosocomial infection followed by gastroenteritis. These were different from other reports, ${ }^{3-5}$ which found gastroenteritis as the most commonly found nosocomial infection. Our results were consistent with those of Garna ${ }^{12}$ which showed skin infection as the most commonly found nosocomial infection,i.e. $32 \%$. The differences in the results of such studies might be caused by several factors, including sampling technique, treatment environment, nurses, mothers, and neonatal factors, as well as many others. ${ }^{13}$

The results of blood culture in those with sepsis and meningitis indicated that enterobacter represent the bacteria as the main cause if bacteremia. Several studies such as that conducted by Gaynes (1996) in the intensive neonatal care unit in Atlanta, for example, finds that group-B streptococcus is the bacteria isolated in greatest number, ${ }^{13}$ while Garna ${ }^{14}$ found that Salmonella sp was the main bacteria isolated. ${ }^{14}$ The difference of the results might be due to the different types of the pathogenic nosocomial bacteria between the respective hospitals. ${ }^{6}$

Birth weight was significantly associated with the occurrence of nosocmial infection. Low birth weight babies were more likely to develop nosocomial infection than those with birth weight $>2500$ gram $(p<0.005)$. Similar result was obtained by Raid in Medan, i.e., low birth weight babies had 9 times more chance to have nosocomial infection than those born with normal weight. ${ }^{4}$ Low birth weight babies, especially those with low gestational age become more easily infected because the imperfect of immunity system and ongan function; they usually need longer in treatment than normal babies so that the chance to have infection also increases.. ${ }^{15,16}$

Mode of delivery was also found associated with the occurrence of nosocomial infection $(p<0.005)$. Babies bom by forcipal or vaccum extraction, tended to be more liable 
to nosocomial infection than those with spontaneous births or with cesarean section. Similar results were also found by Asnil. ${ }^{5}$ One of the risk factors of nosocomial infection is birth trauma; this may explain why babies delivered by intervention tend have more chance for developing nosocomial infection..$^{6,16}$

In conclusion, the incidence of nosocomial infection in this study was $6 \%$, with the male to fernale ratio of 1.6:1. Skin infections were most frequently found nosocomial. This incidence of nosocomial infection was significantly related to birth weight and mode of delivery.

\section{References}

1. Boejang RF, Nosocomial infection from intravenous catheter. Paediatr Indones 1995;35: 78-83.

2. Hamid HA. Neonatology I. Lab. Ilmu Kesehatan Anak FK-UNUD/RSUP Denpasar 1990;76-99.

3. Boejang RF. Gambaran kuman-kuman penyebab infeksi nosokomial pada bayi baru lahir. Presented at KONIKA VI, Denpasar 15-19 Juli 1984.

4. Raid N, Aldy D, Nasution IK et al. Prevalensi infeksi nosokomial di ruang neonatus RS Pirngadi, presented at KONIKA VI, Denpasar 15-19 Juli 1984.

5. Asnil $\mathrm{O}$, Arbi $\mathrm{F}$, Daili $\mathrm{S}$. Kejadian infeksi nosokomial di ruang neonatologi lab. IKA RSUP Dr. Jamil Padang. Presented at KONIKA VI, Denpasar 15-19 Juli 1984.

6. Nelwan RHH. Infeksi nasokomial dan penanganannya. Majalah Kedokteran Indonesia 1989;39: 21-9.

7. Sutoto DAI, Surachmad S. Masalah infeksi nasokomial dan usaha pencegahannya di Indonesia. Presented at KONIKA VI, Denpasar 15-19 Juli 1984.

8. Tim Pokja Infeksi Nasokomial RSUP Denpasar. Buku Pedoman Pokja Pengendalian Infeksi Nasokomial. RSUP Denpasar 1993; 9-33.

9. Soegijanto S, Atmaji D. Penatalaksanaan infeksi nasokomial pada anak. In: Suwendra P. ed. Penatalaksanaan praktís infeksi pada anak. Denpasar: Lab IKA FK-UNUD 1986; 143-157.

10. Vigneswaran R. Surveilence and management of perinatal nasocomial infections. in. Marnoto W, Rachimhadhi T, Pusponegoro T. ed. Penanganan terpadu infeksi perinatal. Jakarta: FKUI 1996: 131.

11. Hamid A. Penanganan infeksi secara praktis pada neonatus. In: Suwendra P. ed. Penatalaksanaan praktis infeksi pada anak. Denpasar, Lab IKA FK-UNUD 1986: 53-75.

12. Garna H. Hospital stay in nasocomial infections. Paediatr Indones 1993;33: 142-9.

13. Gaynes RP, Edward JR, William MS et al. Nasocomial infections among neonates in highrisk nurseries in the United States, Pediatrics 1996;89: 357-61.

14. Garna $H$. The etiology of nasocomial infections in pediatric patients at Department of child health, school of medicine. Pajajaran University Hasan Sadikin General Hospital. Bandung. Paeditr Indones 1993;33; 90-107. 
15. Sarwono E, Kariadi EK, Damanik SM. Bayi berat badan lahir rendah. In: Sarwono E, ed. Continuing education Ilmu Kesehatan Anak. Surabaya FK-UNAIR, 1982: 65-80.

16. Session F, Cloherty JP. Infections: prevention and treatment. In: Cloherty JP, Stark AR. ed. Manual of neonatal care. Boston: Little Brown Company 1980;131-65. 